\title{
Moral face and social face: Contingent self-esteem in Confucian society
}

\author{
Kwang-Kuo Hwang \\ National Taiwan University, Taipei, Taiwan
}

\begin{abstract}
$T$ hree empirical studies related to the Chinese concept of face are reviewed to provide examples of the indigenous approach of Chinese psychology. Using the technique of paired comparison, the first study indicated that college students (who are preparing to enter the job market) feel that they "have face" most when they do well in their academic performance, followed by being morally upright. Retirees (who have withdrawn from the workplace) feel that they "have face" most when their children are morally upright and successful in their careers. The second study (on patterns of emotional reactions of related others to an agent's social and moral incidents) showed, first, that incidents of positive achievement were generally evaluated by college students as being experienced with a more intense feeling of having face than were incidents of positive morality, while incidents of negative morality were experienced with a more intense feeling of "having no face" than were incidents of negative achievement. Second, for a positive incident of having face, the intensity of emotional reaction experienced by acquaintances was generally lower than that of family members. The difference was not so strong as in the negative incident of having no face. The third study (which was a cross-cultural one on cognitive distortion caused by misconduct of related others) indicated that American college students tended to adopt a consistent standard to judge the wrongness of illegal behaviours, regardless of their relationships with the transgressor. But Taiwanese college students tended to judge an illegal behaviour as more wrong when it was done by a person outside the family, while they held a more lenient attitude towards the misconduct of parents, and a similar or more harsh attitude towards their children. Research findings are interpreted in the context of Confucian tradition.
\end{abstract}

7 rois études empiriques reliées au concept chinois de face (défini comme le statut atteint par un individu à travers la reconnaissance sociale de sa performance et de son sens moral) sont examinées afin d'illustrer l'approche indigène de la psychologie chinoise. La première étude a utilisé la technique de la comparaison pairée. Elle a montré que les étudiants collégiens (qui se préparent à entrer sur le marché du travail) sentent surtout qu'ils ont la face quand ils réussissent bien sur le plan académique, suivi par le fait d'être moralement honnête. Les retraités (ceux qui ont quitté leur travail) sentent surtout qu'ils ont la face quand leurs enfants sont moralement honnêtes et ont du succès dans leur carrière. La seconde étude fut effectuée sur les patrons de réactions émotionnelles des personnes proches par rapport à des agents d'événements sociaux et moraux. Elle a montré que les événements de réussite positive étaient généralement évalués par les étudiants collégiens comme étant vécus avec un sentiment plus intense d'avoir la face comparativement aux événements de moralité positive. En contrepartie, les événements de moralité négative étaient vécus avec un sentiment plus intense de ne pas avoir la face comparativement aux événements de réussite négative. En outre, pour un événement positif d'avoir la face, l'intensité de la réaction émotionnelle vécue par les connaissances était généralement plus faible que celle des membres de la famille. La différence n'était pas aussi forte que pour l'événement négatif de ne pas avoir la face. La troisième étude était une étude transculturelle sur la distorsion cognitive causée par la mauvaise conduite de personnes proches. Elle a indiqué que les étudiants collégiaux américains tendaient à adopter un standard logique pour juger l'inexactitude des comportements illégaux, sans tenir compte de leurs relations avec le transgresseur. Mais, les étudiants collégiaux taïwanais tendaient à juger un comportement illégal comme plus incorrect quand il était perpétré par une personne ne faisant pas partie de la famille, tandis qu'ils tenaient une attitude plus indulgente envers les mauvaises conduites de parents ainsi qu'une attitude similaire ou plus sévère envers leurs enfants. Les résultats de recherche sont interprétés dans le contexte de la tradition confucéenne.

Correspondence should be addressed to K.-K. Hwang, Rm 205, South Building, Department of Psychology, National Taiwan University, 1 Roosevelt Road, Sec. 4, Taipei, Taiwan, 106 ROC (E-mail: kkhwang@ntu.edu.tw).

This paper was written with the support of a grant from National Science Council, Republic of China, NSC 93-2752-H-002-001PAE.

(C) 2006 International Union of Psychological Science

http://www.psypress.com/ijp

DOI: $10.1080 / 00207590544000040$ 


\begin{abstract}
$S$ e revisaron tres estudios empíricos relacionados con el concepto de rostro en China como ejemplos del método de la psicología clínica tradicional. Aplicando la técnica de comparación apareada, el primer estudio encontró que la mayor parte de los estudiantes de licenciatura (quienes están preparándose para entrar al mercado laboral) sienten que "tienen un rostro" cuando tienen un buen rendimiento académico, lo cual los hace sentirse moralmente bien. La mayor parte de los pensionados (quienes han dejado de ir al sitio de trabajo) sienten que "tienen un rostro" cuando sus hijos se sienten moralmente bien y tienen éxito en sus carreras. El segundo estudio (sobre los patrones de reacciones emocionales de las personas relacionadas ante los incidentes sociales y morales de un agente) demostró que los estudiantes de licenciatura experimentaban los incidentes de logros positivos con una sensación más intensa de tener rostro que los incidentes de moralidad positiva, mientras que los incidentes de moralidad negativa eran experimentados con una sensación más intensa de "no tener rostro" que los incidentes de logros negativos. En segundo lugar, para un incidente positivo de "tener rostro", la intensidad de la reacción emocional experimentada por los conocidos era, por lo general, menor que la de los familiares. La diferencia no era tan fuerte como en el caso del incidente negativo de no tener rostro. El tercer estudio (un estudio transcultural sobre la distorsión cognitiva causada por la conducta inapropiada de los demás) encontró que los estudiantes de universidades de los Estados Unidos tendían a adoptar una norma consistente para juzgar lo incorrecto de las conductas ilegales, sin importar las relaciones que establecieran con el transgresor. Sin embargo, los estudiantes universitarios de Tasmania tendían a considerar incorrecta una conducta ilegal cuando se trataba de una persona ajena a la familia, y tenían una actitud más laxa hacia los problemas de comportamiento de los padres, y una actitud similar o más ruda hacia los hijos. Los resultados experimentales se interpretan en función del contexto de la tradición confuciana.
\end{abstract}

In Western social psychology, "face" is conceptualized as an individual's situated identity, or identity in a particular situation (Alexander \& Rudd, 1981). In Confucian culture, face can be defined as an individual's contingent self-esteem (Ng, 2001), or as a person's cognitive response to social evaluation of his conduct in a particular situation. Face may have impact on a person's emotional state, or urge a person to take action to restore face. In any culture, an individual may experience a feeling of having or losing face because of positive or negative social evaluation (e.g., Goffman, 1959; Ting-Toomey, 1994), although face has special connotations in Chinese society (Ho, 1976; Hu, 1944; Hwang, 1987; Stover, 1974); this can be illuminated in the context of Confucian relationalism.

This article presents findings of several empirical studies on Chinese face. It is expected that the specific features of Chinese social behaviour can be illustrated by (1) social incidents that induce a feeling of having face or losing face, (2) the emotional reactions of related others to one's social incidents, and (3) one's cognitive distortion caused by misconduct of related others that may make one lose face.

\section{MORAL FACE AND SOCIAL FACE}

In Chinese society, there are clearly two types of face: social face and moral face (Cheng, 1986; Hu, 1944). Social face is gained either through the status achieved by one's talent, endeavours, or ability; or through the status ascribed by one's consanguineous relationships. Moral face refers to the social evaluation of one's moral character, which is the baseline of one's integrity of personality. An individual may choose not to strive for social face, but must protect moral face in all situations.

Based on these propositions, it might be expected that the importance of social face for college students and retired people might differ. College students are preparing to enter the job market to pursue career success, so they tend to value the social face achieved through academic performance. Retirees have withdrawn from the workplace. They may no longer care about their own career performance, but may experience the feeling of having or losing face through the achievements of their family members, especially their children. Nevertheless, both college students and retirees should care about their own moral face.

Based on such reasoning, Su and Hwang (2003) used a paired comparison technique with 56 retirees and 54 college students to examine the extent of the feeling of "having face" arising from the moral or academic (or career) performance of themselves, their children (or parents), or their friends. The same method was used to compare the extent of the feeling of "losing face" experienced when their own (or their family member's or friend's) immoral conduct or academic (or career) failure was exposed in public. The scores of original means were calculated by using the paired 
comparison method (Thurstone, 1927). The numerical values represent the extent of having or losing face for various incidents experienced by the participants.

\section{Social incidents of having face}

The first two incidents that make retirees most feel they "have face" are when their children are morally upright (0.719) and successful in their careers $(0.647)$. The next two incidents pertain to their own performance $(0.495 ;-0.004)$; and the last two relate to their friends $(-0.686 ;-1.116)$.

Results show that the order of the first two pairs for college students is opposite to that of retirees. Because college students hope to enter the job market soon, they most feel they "have face" when they do well in their academic performance (1.312), followed by being morally upright (1.231). Next in importance is when their parents are morally upright $(0.151)$ and successful in their careers $(-0.087)$, and last is when their friends are morally upright $(-1.026)$ and have a good academic performance $(-1.581)$.

In comparing the data of retirees with that of college students, several points should be noted. First, the distribution of incidents on the similarity scale for paired comparisons made by retirees is more concentrated than that made by college students, implying that college students are able to make more distinct cognitive differentiations between the incidents than retirees. Second, being morally upright conveys more face than academic or career performance for all agents, except college students, who indicated that their academic performance (1.312) is relatively more important than being morally upright (1.231), although the difference is not significant. The data reflect an important fact about Chinese face: In general, moral face is more basic and important to most people than social face earned through the achievements of oneself or one's family (Cheng, 1986).

Third, one's own achievement and moral performance may make college students feel that they have more face than their parents, which reflects an individual orientation. In contrast, retirees have face more from their children's moral performance and academic achievements than from their own, which reflects a social (Yang, 1981) or relational orientation (Ho, 1991; Hwang, 2001). In other words, "individual orientation" or "social orientation" should be regarded as patterns of behaviour that might be elicited by a particular situational context, rather than a stable personality orientation or national character.

\section{Social incidents of losing face}

Moral face is the baseline for being an upright person, which should not be lost in any situation. Once it is lost, it is very hard for an individual to maintain a position in the community.

Results show that the incident that caused retirees the most serious feeling of losing face was personal moral deficiency (1.698). The next most serious was the moral deficiency of their son or daughter (1.229), personal career failure (0.54), and then failure of their son or daughter (0.508). Moral deficiency $(-1.055)$ or career failure $(-2.924)$ of a friend ranked lowest. The whole sequence reflects the differential structure of Chinese relationalism: Individuals tend to maintain psychosocial homeostasis by arranging interpersonal relationships with others from intimate to remote (Fei, 1948; Hsu, 1971; Hwang, 2000, 2001).

Though the mean scores reflecting the extent of losing face for various incidents were different for college students and retirees, the sequence was similar. The only exception was for college students, where the moral deficiency of a friend $(-0.108)$ brought a stronger feeling of losing face than the career failure of parents $(-1.509)$. When a college student has a friend with a moral deficiency, s/he might be treated similarly to the friend, or even be similarly accused by others. But if a friend has poor academic performance, an individual might feel enhanced face through downward social comparison. Thus, this incident ranked lowest in the extent of making a college student feel the loss of face $(-2.837)$.

\section{RELATIONALISM AND EMOTIONAL REACTION}

Because college students are preparing to pursue careers, academic achievement is more important than being morally upright, and social face is more important than moral face in terms of the feeling of having face. However, moral face is the baseline of the integrity of personality. Although an individual may not strive for it, he should be careful not to lose it in any situation. Moral face is more important than social in terms of losing face.

In Confucian culture, when an individual violates a moral rule, a person's reaction may depend on that person's relationship with the agent. Liu (2002) asked 278 university students (150 men and 128 women) in Taiwan to read four scenarios about incidents of achievement or morality. The agent in the positive moral scenario helped a woman who fainted on the street to go to 
the hospital and saved her life. The agent in the positive achievement scenario was a student who had failed the Joint Entrance Examination for admission to a university, but he eventually passed the examination through hard work. The agent in the negative moral scenario was caught stealing from a store by the police. The agent in the negative achievement scenario dropped out of school due to poor grades. Participants were asked to evaluate the emotional reactions of people of different role relationships with the agent on a 7point scale. The mean scores for emotional reactions were then calculated.

Figures 1 and 2 present the emotional reactions of "having face" and "having no face" as evaluated by the participants for each role. Two remarkable points should be noted: First, as predicted, incidents of positive achievement were generally evaluated by college students to be experienced with a more intense feeling of having face than incidents of positive morality (see Figure 1). Incidents of negative morality were experienced with a more intense feeling of "having no face" than incidents of negative achievement (see Figure 2). Second, for a positive incident of having face, the intensity of emotional reaction experienced by acquaintances (including good friends, classmates, and teachers) was generally lower than that of family members. The difference was not so drastic as in the negative incident of having no face.

In other words, participants believed that acquaintances and family members might experience a similar intensity of face for one's positive incidents. When an individual suffers from a negative incident of having no face, family members may also experience a feeling of having no face, but acquaintances may sever relationships and thus will not experience a similar feeling of having no face. The pattern of emotional reactions reflects the Chinese conceptualization of family as a whole body sharing the experience of having face or losing the face. While one's acquaintances may share positive incidents, they do not seem to share the negative ones.

\section{COGNITIVE DISTORTION}

Because family members are perceived as parts of a body, if any one member of the family does

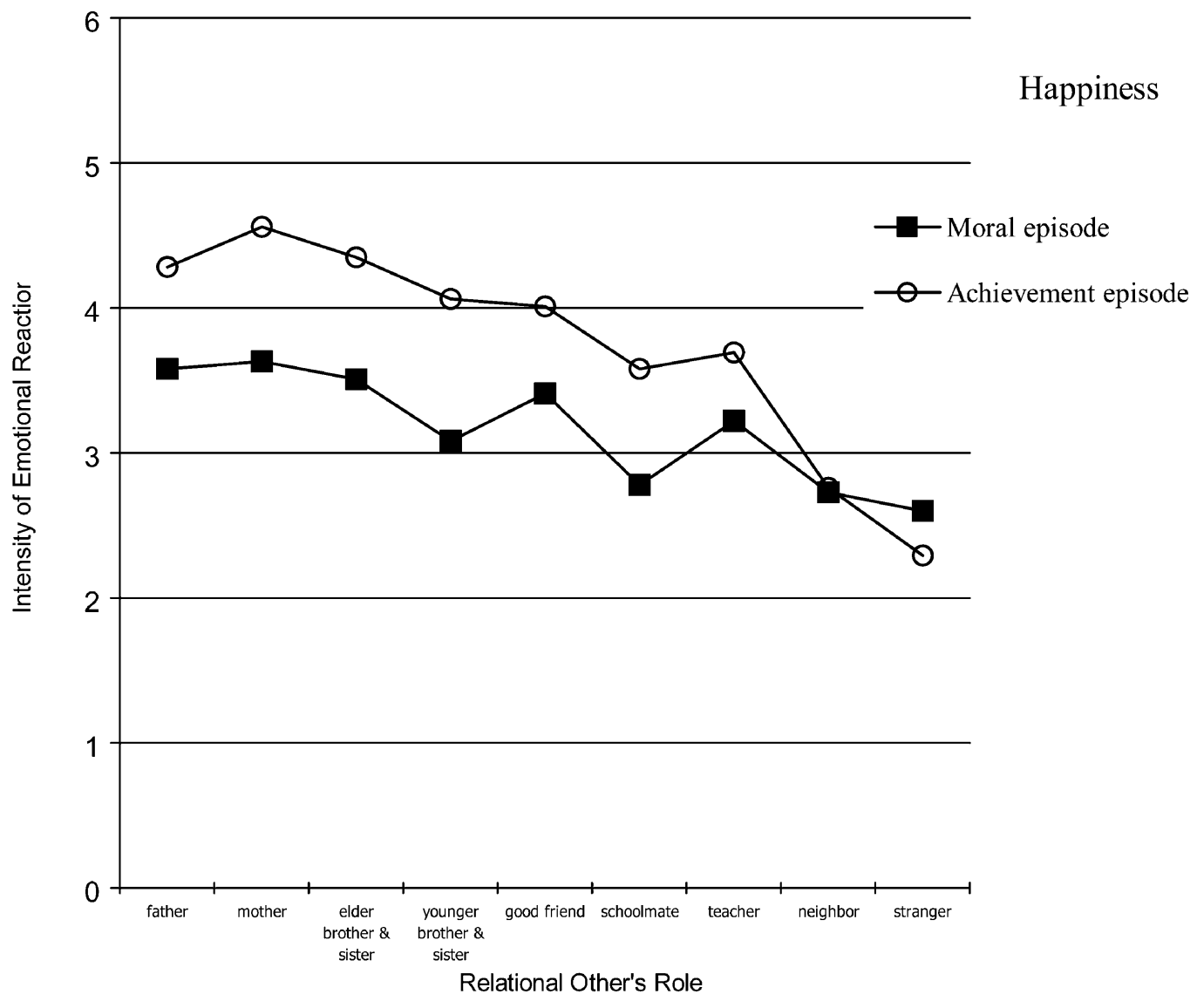

Figure 1. Relational other's emotional reaction to agent's positive episode. 


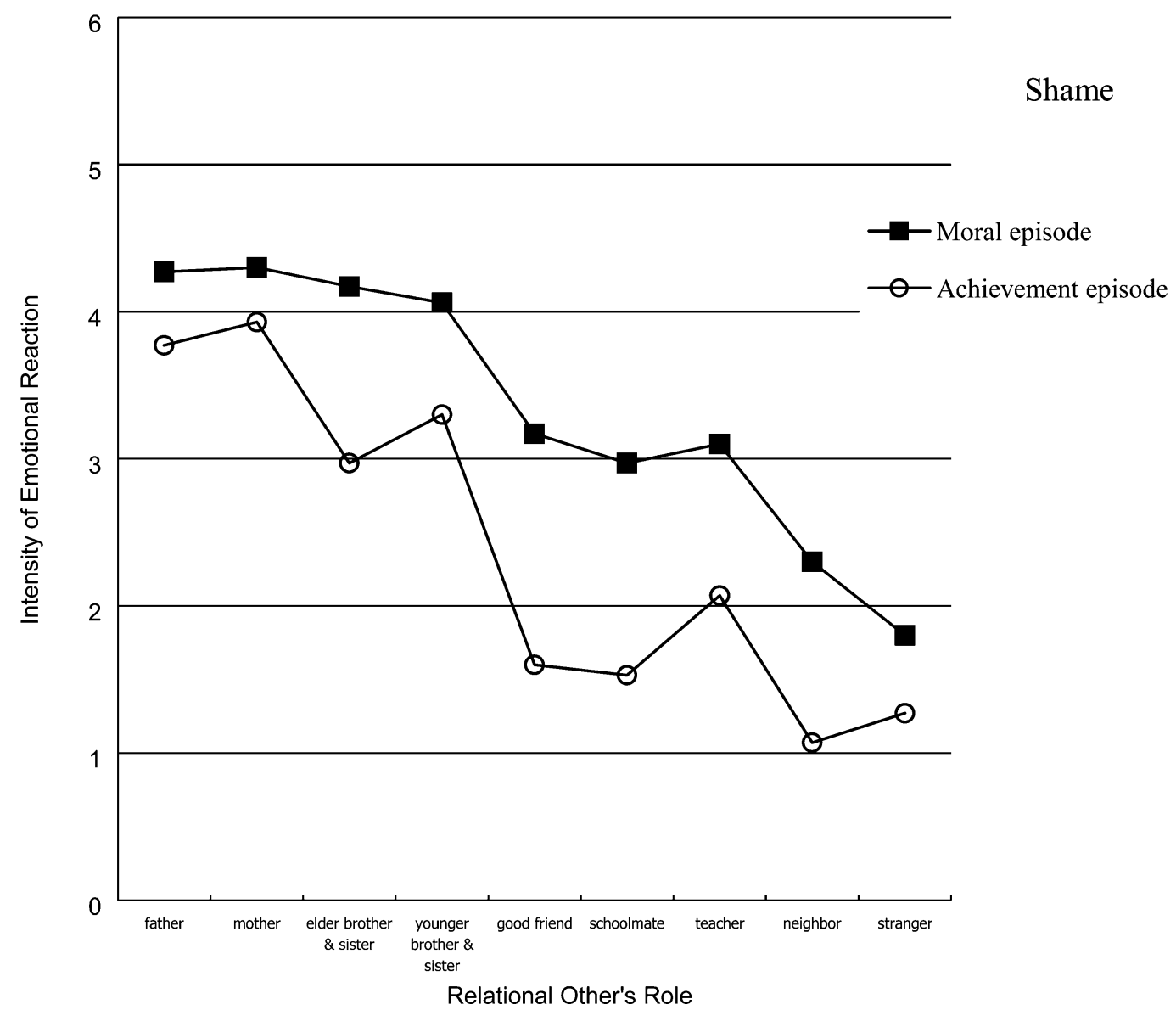

Figure 2. Relational other's emotional reaction to agent's negative episode.

something immoral, all family members may suffer from loss of face. Such a feeling may have an impact on one's moral judgment and result in cognitive distortion, which may reflect specific features of Confucian ethics and can be illustrated with a cross-cultural study on moral judgment between Taiwanese and American college students (Wei \& Hwang, 1998).

In the second part of their study, 194 Taiwanese and American college students were asked to evaluate the extent of wrongness involved when a person violates negative duties towards different social targets. Responses to 20 items were subjected to factor analysis and three factors were obtained.

Factor 1 was labelled Violating the Social Norm and entailed behaviours that either destroy the social order or are prohibited by the law. It consisted of six items including "giving a gift to bribe someone or being bribed," "trying to be first and not standing in a queue," "tax evasion," "using insider information to make a profit in the stock market," "littering," and "maltreating one's child."

American subjects evaluated all behaviours described by the items of this factor as having a higher degree of wrongness than did Chinese subjects, no matter who the transgressor was (see Figure 3). American participants gave the different social targets only minor differences in scores, while Taiwanese allocated scores that increased as a function of the remoteness of the relationship with the transgressor. In other words, American college students tended to adopt a consistent standard to judge the wrongness of illegal behaviours, regardless of their relationships with the transgressor. However, Taiwanese college students tended to judge an illegal behaviour as being more wrong when it was done by a person outside the family, while they held a more lenient attitude towards the misconduct of parents (for the sake of protecting their face), and a similar or more harsh attitude towards their children (a necessity of disciplining them).

\section{CONCLUSION}

Concern about public image might be universal to people in various cultures, but the specific features of Chinese social behaviour related to face should 


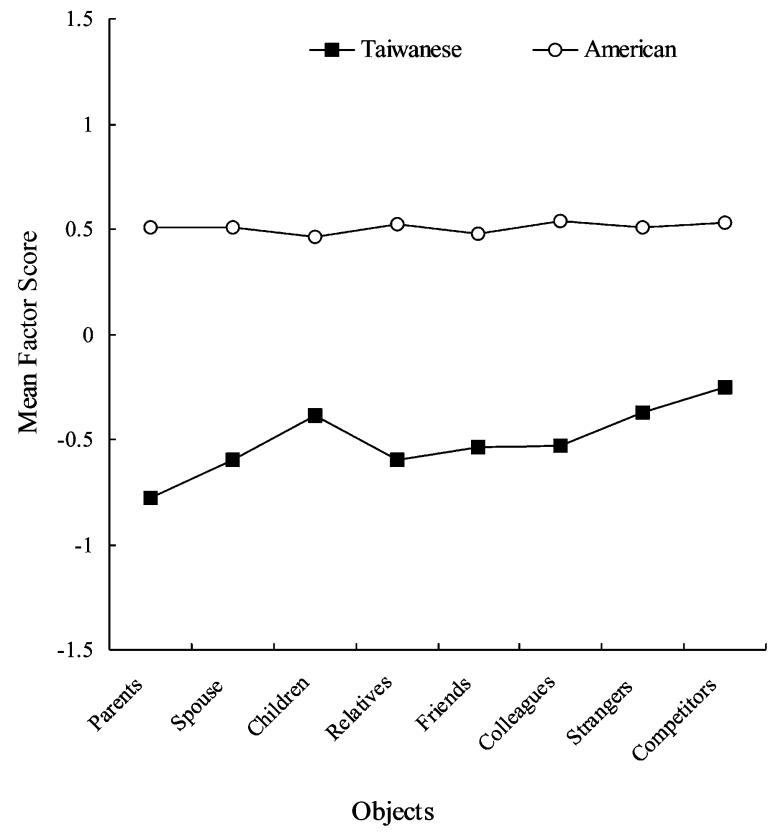

Figure 3. Factor scores on "violating law" by Taiwanese and American students.

be understood in the context of Confucian cultural traditions. It is expected that the empirical studies reviewed in this article, in combination with the theoretical modes of Confucian relationalism (Hwang, 2000, 2001), may help the reader to understand the indigenous approach of Chinese psychology.

\section{REFERENCES}

Alexander, C. N., \& Rudd, J. (1981). Situated identities and response variables. In J. T. Tedeschi (Ed.), Impression management theory and social psychological research (pp.83-103). New York: Academic Press.

Cheng, C. Y. (1986). The concept of face and its Confucian roots. Journal of Chinese Philosophy, 13, 329-348.
Fei, S. T. (1948). Rural China. [in Chinese]. Shanghai: Observer.

Goffman, E. (1959). The presentation of self in everyday life. New York: Doubleday, Anchor.

Ho, D. Y. F. (1976). On the concept of face. American Journal of Sociology, 81, 867-884.

Ho, D. Y. F. (1991). Relational orientation and methodological relationalism. Bulletin of the Hong Kong Psychological Society, 26-27, 81-95.

Hsu, F. L. K. (1971). Psychological homeostasis and ren: Conceptual tools for advancing psychological anthropology. American Anthropologist, 73, 23-44.

$\mathrm{Hu}, \mathrm{H}$. C. (1944). The Chinese concepts of "face". American Anthropologist, 46, 45-64.

Hwang, K. K. (1987). Face and favor: The Chinese power game. American Journal of Sociology, 92, 944-974.

Hwang, K. K. (2000). Chinese relationalism: Theoretical construction and methodological considerations. Journal for the Theory of Social Behavior, 30, 155-178.

Hwang, K. K. (2001). The deep structure of confucianism: A social psychological approach. Asian Philosophy, 11, 179-204.

Liu, D. W. (2002). Relational others' emotional reactions to negative episodes of agency evaluated by college students in Taiwan. Unpublished master thesis, National Taiwan University, Taiwan.

$\mathrm{Ng}$, A. K. (2001). Why Asians are less creative than Westerners. Singapore: Prentice-Hall.

Stover, L. E. (1974). The cultural ecology of Chinese civilization. New York: Pica Press.

Su, S. Y., \& Hwang, K. K. (2003). Face and relation in different domains of life: A comparision between senior citizens and university students. Chinese Journal of Psychology, 45, 295-311.

Thurstone, L. L. (1927). A law of comparative judgment. Psychological Review, 34, 273-286.

Ting-Toomey, S. (1994). The challenge of facework: Cross-cultural and interpersonal issues. New York: State University of New York Press.

Wei, C. F., \& Hwang, K. K. (1998). Positive duties and negative duties: A cross-cultural comparison of moral judgment between Taiwanese and American college students. Chinese Journal of Psychology, 40, 137-153.

Yang, K. S. (1981). Social orientation and individual modernity among Chinese students in Taiwan. Journal of Social Psychology, 113, 159-170. 
Copyright of International Journal of Psychology is the property of Routledge and its content may not be copied or emailed to multiple sites or posted to a listserv without the copyright holder's express written permission. However, users may print, download, or email articles for individual use. 